\title{
NILAI ORGANOLEPTIK BAKSO IKAN LAYANG (Decapterus russelli), IKAN KUNIRAN (Upeneus moluccensis) DAN IKAN NILA (Oreochromis niloticus)
}

\author{
Organoleptic Properties of Fish Ball from Scad (Decapterus russelli) Kuniran (Upeneus \\ moluccensis) and Nile Tilapia (Oreochromis Niloticus) Fish
}

\author{
Thania Kahiking, Novalina Maya Ansar, Eko Cahyono \\ Program Studi Teknologi Pengolahan Hasil Laut, Politeknik Negeri Nusa Utara \\ Email: ekocahyono878@gmail.com
}

\begin{abstract}
Abstrak: Bakso ikan merupakan produk berbahan dasar dari surimi yang terbuat dari lumatan daging ikan yang telah mengalami proses penghilangan tulang, dan sebagian komponen larut air dan lemak melalui pencucian dengan air, sehingga disebut sebagai konsentrat basah protein myofibril dari daging ikan layang, kuniran, dan nila. Tujuan penelitian adalah untuk mengetahui mutu bakso dari berbagai jenis daging ikan yang digunakan. Metode yang digunakan dalam penelitian ini adalah eksperimental. Hasil uji ogranoleptik menunjukkan bakso dengan kategorikategori berikut, kenampakan terbaik pada ikan nila $(8,2)$, bau terbaik dari ikan kuniran $(7,8)$, rasa terbaik pada ikan layang $(8,8)$ dan tekstur terbaik pada ikan layang $(8,8)$. Kesimpulan dari ketiga jenis bahan baku yang digunakan ikan kuniran merupakan bahan baku terbaik dalam pembuatan bakso.
\end{abstract}

Kata kunci: bakso, kuniran, layang, nila, organoleptik.

\begin{abstract}
Abtract: Fish ball is a surimi-based product made from ground fish meat that has undergone a bone removal process as well as elimination of water and fat soluble components through washing with water. Hence, it is called wet concentrated myofibril protein mainly derived from mackerel scad, goldband goatfish, and tilapia meat. The objective of this research was to determine the quality of fish balls from various types of fish (mackerel scad, mac). Organoleptic tests showed that the best appearance, smell, taste and texture categories were found in tilapia (8.2), goatfish (7.8), mackerel scad (8.8), and mackerel scad (8.8) respectively. As a conclusion, of the three raw materials used in this research, goldband goatfish proved to be the best source of raw material for fish balls.
\end{abstract}

Keyword: fish ball, goldband goatfish, mackerel scad, organoleptic, tilapia

\section{PENDAHULUAN}

Komoditas hasil perikanan yang cukup unggul di Kepulauan Sangihe adalah ikan layang (Decapterus russelli) mewakili jenis pelagis, Ikan Kuniran (Upeneus moluccensis) mewakili jenis demersal dan Ikan Nila (Oreochromis niloticus) mewakili jenis air tawar (Setiawan et al. 2016). Komoditas hasil perikanan ini umumnya belum dilakukan diversifikasi dan pengembangan produk berbasih berbarbagai jenis ikan.

Ikan merupakan salah satu komoditi yang mudah mengalami kerusakan (high perishable) (Kusumayanti et al. 2011). Menurut Afrianto (2010) daging ikan merupakan salah satu sumber protein hewani yang sangat potensial untuk pemenuhan kebutuhan protein, karena mempunyai kandungan gizi yang tinggi dan asam amino esensial yang berguna bagi tubuh. Menurut
Ferantika et al. (2020) daging ikan kembung mengandung protein 9,94-12,46\%; Hadinoto dan Kolanus (2017) daging ikan layang mengandung protein 26,31\%; Tondais et al. (2020) daging kuniran mengndung protein $18,71 \%$; Palupi et al (2020) daging ikan nila mengandung $15,40 \%$. Menurut Sitepu et al. (2020) kandungan air yang cukup tinggi pada tubuh ikan menjadi media yang cocok untuk kehidupan bakteri pembusuk dan organisme lain, sehingga ikan sangat mudah mengalami proses pembusukan. Salah satu cara dalam memutus rantai pembusukan dengan melakukan diversifikasi produk. Salah satu produk diversifikasi adalah bakso ikan.

Bakso merupakan salah satu makanan khas Indonesia yang sangat populer dan cukup digemari. Di Indonesia umumnya bakso berbahan baku daging sapi, ayam dan ikan (Manuhara et al. 2015). 
Bakso ikan merupakan produk berbahan dasar dari surimi yang terbuat dari lumatan daging ikan yang telah mengalami proses penghilangan tulang, dan sebagian komponen larut air dan lemak melalui pencucian dengan air, sehingga disebut sebagai konsentrat basah protein myofibril dari daging ikan (Astuti et al. 2014).

Protein miofibril merupakan bagian terbesar dari jaringan daging ikan yang larut dalam larutan garam (Apituley dan Tamaela 2014). Protein ini terdiri dari miosin, aktin, tropomiosin, serta aktomiosin yang merupakan gabungan aktin dan miosin. Protein miofibril berperan dalam pembentuk gel dan proses koagulasi, terutama dari aktomiosin (Junianto 2003). Berdasarkan hasil penelitian Apituley dan Tamaela (2014) protein miofobril yang terkandung pada ikan pelagis berkisar antara $15.58-16.97 \%$ dan ikan demersal antara 12,10-13,69\%. Menurut Gultom et al. (2015) protein myofibril pada ikan air tawan berkisan antara 3,40-4,39 mg/g.

Sifat fungsional protein miofibril didefinisikan sebagai sifat-sifat protein yang dapat mempengaruhi karakter pangan selama pengolahan, penyimpanan dan konsumsinya, sehingga menentukan penggunaannya dalam pangan. Sifat yang disebabkan oleh interaksi protein dengan komponen-komponen lainnya, baik langsung maupun tidak langsung akan berpengaruh pada proses aplikasinya, mutu dan penerimaan bahan (Subagio et al. 2004). Pada Praktek Kerja Akhir ini dilakukan proses pembuatan bakso dengan berbagai jenis daging ikan dari kategori pelagis adalah ikan layang, kategori demersal adalah ikan kuniran, dan kategori ikan air tawar adalah ikan nila. Tujuan penelitian adalah untuk mengetahui mutu bakso dari berbagai jenis daging ikan yang digunakan.

\section{METODE PENELITIAN Alat dan Bahan}

Alat yang digunakan dalam penelitian panci pengukus, blender, pisau, talenan, kompor, baskom atau loyang, dan timbangan. Bahan yang dibutuhkan daging ikan berbaagai jenis (ikan layang, kuniran, dan nila) masing-masing 500 gram, tepung tapioka 15 gram, garam 10 gram, bawang putih 10 gram, merica 1,5 gram, gula 3,75 gram, 3 butir telur, es batu secukupnya.

\section{Proses Pembuatan Bakso}

Proses pembuatan bakso ikan merujuk pada penelitian Zamili et al. (2020) yang dimodifikasi dengan menyiapkan bahan utama (daging ikan layang, kuniran, dan nila). Memisahkan daging, tulang, dan durinya dengan cara menyayat memanjang pada bagian punggung hingga terbelah menjadi dua bagian. Mengambil bagian daging ikan dengan cara mengerok dengan sendok. Merendam daging ikan dalam air dingin selama \pm 1 menit sembari diaduk. Hancuran daging yang telah terkumpul selanjutnya dibersihkan dari kompenen yang tidak dikehendaki (kulit, duri dan tulang). Membuang kotoran dan lemak jika timbul atau mengapung dipermukaan. Melumatkan daging daging ikan dengan alat penggiling (blender). Memasukkan daging ikan sambil diberi garam (10 gram) sedikit demi sedikit hingga daging menjadi lumat. Menghaluskan bumbubumbu ke dalam lumat daging dan masukkan tapioka sedikit demi sedikit. Untuk meningkatkan elastisitas dari adonan bakso diberi satu butir putih telur untuk setiap 500 gram adonan bakso. Mengaduk-aduk adonan bakso sampai homogen dan tidak lengket ditangan. Proses pembentukan bakso dilakukan dengan pencetakan membuat bola-bola kecil dengan cara adonan diletakan pada telapak tangan, dikepal-kepal kemudian ditekan ssehingga keluar bola-bola bakso dari sela-sela ibu jari dan jari telunjuk. Bola-bola bakso yang keluar dari kepalan itu diangkat dengan sendok. Merebus bola-bola bakso dalam air mendidih hingga bakso mengapung sebagai tanda telah matang. Angkat dan tiriskan.

\section{Analisa Data}

Data organoleptik dianalisis menggunakan Kruskal Wallis disajikan dengan ANOVA. Apabila terdapat perbedaan yang nyata, dilanjutkan dengan uji Beda Nyata Jujur (BNJ).

\section{HASIL DAN PEMBAHASAN Nilai Kenampakan}

Kenampakan merupakan parameter organoleptik yang penting, karena merupakan sifat sensoris yang pertama kali dilihat oleh konsumen. Menurut Karim et al. (2014) kesan pertama yang dirasakan oleh konsumen pada saat melihat suatu produk biasanya lewat rupa atau penampakan dari produk tersebut dan pada umumnya konsumen lebih memilih produk yang memiliki rupa yang menarik. Warna juga memberikan petunjuk mengenai perubahan kimia dalam makanan. Nilai kenampakan dapat dilihat pada Gambar 1. 


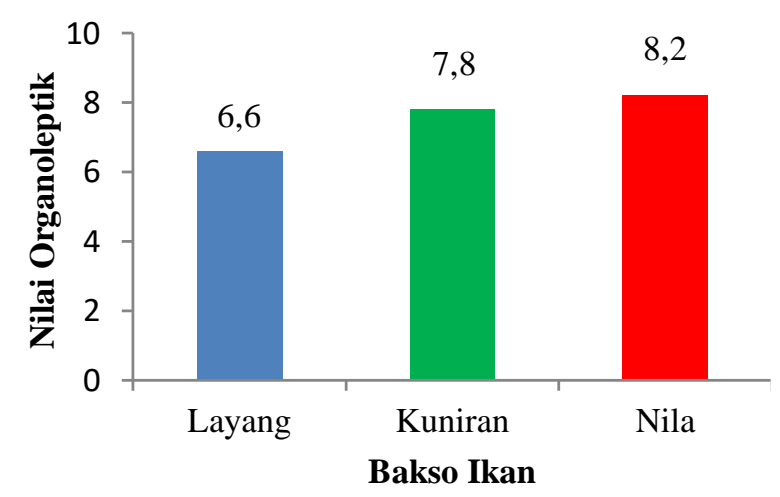

Gambar 1. Histogram Nilai Kenampakan

Histogram di atas menunjukkan bahwa nilai rata-rata uji sensori kenampakan pada bakso ikan layang $(6,6)$, ikan kuniran $(7,8)$, dan ikan nila $(8,2)$. Berdasarkan SNI (2014) nilai sensori bakso ikan kuniran dan bakso ikan nila masih sesuai dengan standar yang ditetapkan (minimal 7,0). Hal ini dikarenakan bakso ikan nila memiliki tekstur yang cukup halus, bulat, sedikit beronggga dan cenderung berwarna cerah (putih) dan bakso ikan kuniran memiliki bentuk yang kurang halus, sedikit berongga dan berwarna cerah. Menurut Paliling et al (2018), bakso ikan dengan penambahan ekstra karotenoid dari udang putih memiliki kriteria permukaan cukup halus, tidak berongga dan berwarna cerah. Pada penelitian pembuatan bakso ikan dilakukan proses pembentukan secara manual sehingga bentuk yang dihasilkan cenderung tidak seragam berdasarkan kategori kenampakan. Menurut SNI (2014), spesifikasi kenampakan bakso ikan kuniran dan nila masih sesuai standar (Min 7,0) dengan kriteria (7-9) yaitu permukaan kurang halus hingga halus, sedikit berongga sampai tidak berongga dan warna kurang cerah hingga cerah.

\section{Nilai Bau}

Pembauan disebut juga pencicipan jarak jauh dengan menggunakan indera penciuman. Menurut Winarno (2004) aroma dalam makanan dalam banyak hal menentukan enak atau tidaknya makanan bahkan aroma atau bau-bauan lebih kompleks daripada rasa dan kepekaan indera pembauan biasanya lebih tinggi dari indera pencicipan bahkan industri pangan menganggap sangat penting terhadap uji bau karena dapat dengan cepat memberikan hasil penilaian apakah enak atau tidak. Nilai bau dapat dilihat pada Gambar 2.

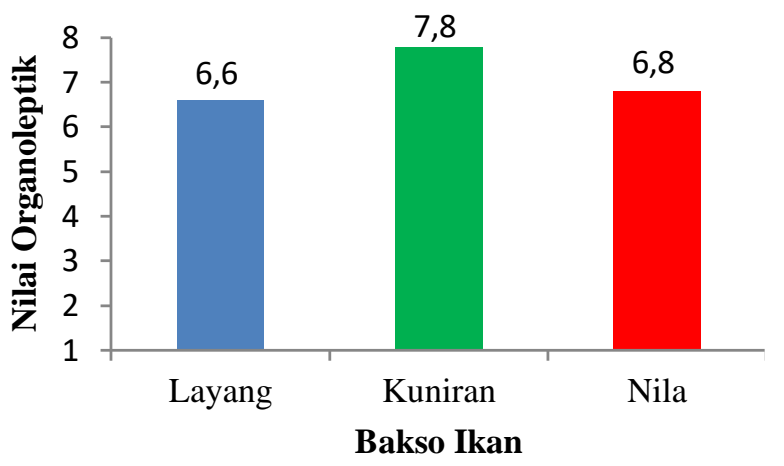

Gambar 2. Histogram Nilai Bau

Berdasarkan histogram di atas, nilai ratarata uji sensori bau pada bakso ikan layang $(6,6)$, ikan kuniran $(7,8)$, dan ikan nila $(6,8)$. Hal ini dikarenakan ikan kuniran memiliki kandungan lemak yang rendah sehingga tidak mengeluarkan bau amis yang kuat. Menurut Sedayu et al. (2015) kadar lemak ikan kuniran $(0,88 \%)$. Lebih lanjut Subagio et al, (2004) menjelaskan bahwa ikan kuniran memiliki lemak relatif rendah sehingga tidak mengeluarkan bau amis. Ini berbeda dengan ikan layang dan nila yang memiliki kadar lemak tinggi. Hadinoto dan Kolanus (2017) melaporkan bahwa lemak ikan layang $(1,90 \%)$ dan Palupi et al. (2020) melaporkan lemak nila sebesar 6,09\%. Tinggi rendahnya kadar lemak pada bahan baku mempengaruhi produk bakso. Disisi lain geosmin (bau lumpur) pada ikan nila sangat mempengaruhi nilai sensori dari produk bakso. Menurut Insan et al. (2004), geosmin pada ikan air tawar sangat mempengaruhi cita rasa dari produk. Spesifikasi bau bakso ikan kuniran (Min 7.0) dalam studi ini masih sesuai dengan SNI (2014) dengan kriteria (79) untuk bau khas produk.

\section{Nilai Rasa}

Rasa adalah nilai yang sangat menentukan dalam penerimaan konsumen terhadap produk pangan. Rasa dipengaruhi oleh beberapa faktor seperti kosentrasi dan interaksinya dengan kompenen lain. Menurut Rozaliana et al (2012), Cahyono dan Rieuwpassa (2017), asam amino merupakan salah satu kompenen pembentuk bau dan rasa. Asam amino yang terdapat pada protein ikan dalam pangan dapat mempengaruhi rasa manis, gurih bahkan pahit. Nilai rasa dapat dilihat pada Gambar 3. 


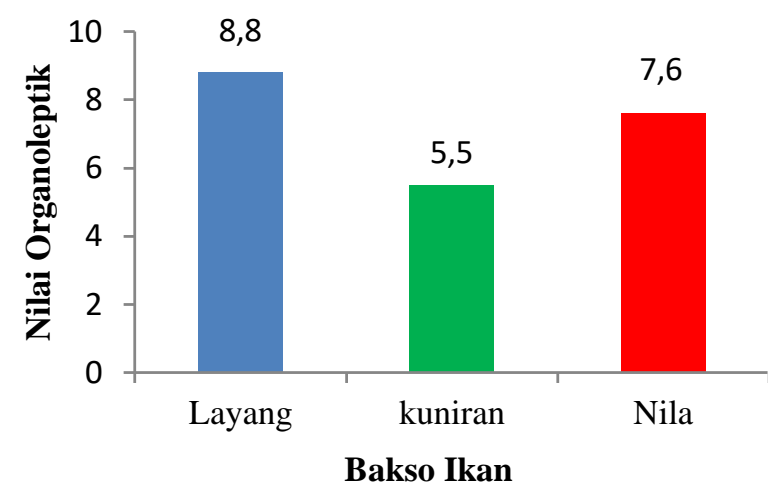

Gambar 3. Histogram Nilai Rasa

Berdasarkan histogram di atas, nilai ratarata uji sensori rasa pada bakso ikan layang $(8,8)$, bakso ikan kuniran $(5,5)$, dan bakso ikan nila $(7,6)$. Dari hasil uji sensori, panelis lebih cenderung menyukai bakso ikan layang dibandingkan bakso ikan nila dan kuniran. Hal ini dikarenakan rasa gurih yang ditimbulkan dari penambahan bahan tambahan (garam, merica, bawang putih dan gula) dan pembentukan tekstur yang kenyal. Purukan et al. (2013) dan Ardianti et al (2014) menjelaskan bahwa penambahan bumbu-bumbu pada bakso memberikan pengaruh terhadap cita rasa dari produk. Berdasarkan SNI (2014) rasa bakso ikan nila dan layang masih sesuai standar (Min 7,0) dengan kriteria (7-9) yaitu spesifik produk kurang dan spesifik produk.

\section{Nilai Tekstur}

Tekstur merupakan salah satu sifat bahan atau produk yang dapat dirasakan melalui sentuhan kulit atau pencicipan. Tekstur dapat dirasakan dengan menggunakan tekanan pada produk tersebut. Menurut Astuti et al. (2014), air dalam adonan menyebabkan proses gelatinisasi menjadi kurang sempurna, sehingga bakso yang dihasilkan menjadi cenderung keras, selain itu tekstur yang rapuh dapat terjadi akibat tidak cukup kuatnya lemak atau minyak protein. Montolalu et al. (2013), menyatakan bahwa bakso akan mengikat air rebusan, selain terjadi pengikatan air, juga terjadi pelepasan atau pelarutan zat-zat gizi tertentu seperti protein, lemak karbohidrat vitamin dan mineral. Nilai tekstur dapat dilihat pada Gambar 4.

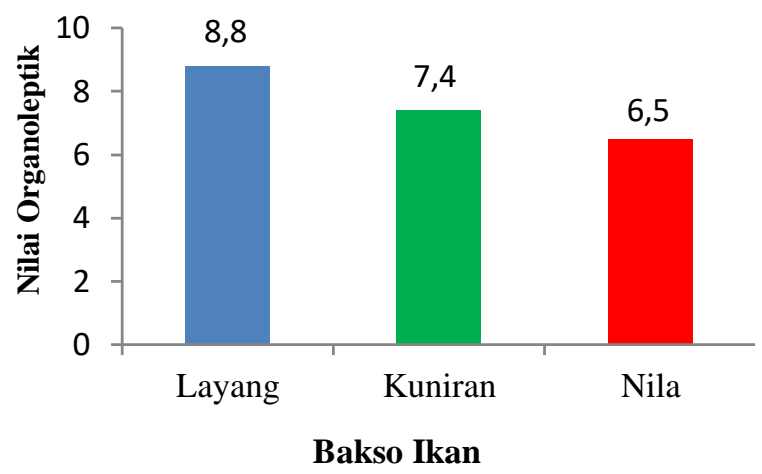

Gambar 16. Histogram Nilai Tekstus

Berdasarkan histogram di atas menunjukkan bahawa nilai rata-rata uji sensori Tekstur pada bakso ikan layang $(8,8)$, bakso ikan kuniran $(7,4)$, dan bakso ikan nila $(6,5)$. Tingginya nilai tekstur dikarenakan jumlah protein miofibril pada ikan pelagis jauh lebih besar dibandingkan dengan ikan demersal dan ikan air tawar. Hal ini sejalan dengan penelitian Apituley dan Tamaela (2014) yang menjelaskan bahwa nilai protein miofibril ikan pelagis lebih tinggi dibandingkan dengan ikan demersal selama waktu penyimpanan dingin antara 0-4 hari. Berdasarkan penelitian adonan daging lumat ikan layang jauh lebih kompak dibandingkan dengan daging lumat ikan kuniran dan ikan nila. Menurut Irianto dan Giyatmi (2009) menjelaskan bahwa kemampuan pembentukan gel daging lumat dipengaruhi oleh jumlah protein miofibril dalam daging. Protein miofibril berperan terhadap elastisitas dan daya ikat air pada daging, serta tekstur pada produk daging lumat. Menurut Subagio et al. (2004) protein miofibril ikan kuniran (30-33\%); Hasani (2010) protein miofibril ikan nila (20\%). Perbedaan persentasi protein miofibril sangat menentukan tingkat elastisitas atau kekompakan pada produk bakso. Menurut SNI (2014) spesifikasi tekstur bakso ikan kuniran dan layang masih sesuai standar (Min 7,0) dengan kriteria (79) yaitu padat, kampok, kenyal, dan agak kenyal.

\section{KESIMPULAN}

Berdasarkan hasil penelitian dapat disimpulkan bahwa nilai sensori bakso ikan untuk kategori kenampakan yang terbaik pada bakso ikan nila $(8,2)$, kategori bau terbaik pada bakso ikan kuniran $(7,8)$, kategori rasa yang terbaik pada bakso ikan layang $(8,8)$, dan katogori tekstur pada bakso ikan layang $(8,8)$. Dari ketiga jenis bahan baku yang digunakan ikan kuniran merupakan bahan baku terbaik dalam pembuatan bakso. 


\section{DAFTAR RUJUKAN}

Ardianti Y, Widyastuti S, Rosmilawati SW, Handito D. 2018. Pengaruh penambahan karagenan terhadap fisik dan organoleptik bakso ikan tongkol (Euthynnus affinis). Majalah Ilmiah Pertanian. 24(3):159-166.

Arifianto T. 2010. Karakteristik Bakso Ikan Nila dengan Penambahan Karaginan Semimurni. [Skripsi]. Institut Pertanian Bogor. Bogor

Astuti RT, Darmanto YS, Wijayanti I. 2014. Pengaruh Penambahan Isolat Protein Kedelai Terhadap Karakteristik Bakso Dari Surimi Ikan Swangi (Priacanthus tayenus). Jurnal Pengolahan dan Bioteknologi Hasil Perikanan. 3(3):47-54

Cahyono E, Rieuwpassa JF. 2017. Analisis asam amino beberapa jenis teripang olahan kering di Kabupaten Kepulauan Sangihe. Jurnal Ilmiah Tindalung. 3(1):36-42

Ferantika NC, Haryati S, Larasati D. 2020. Karakteristik Fisiokimia dan Organoleptik Bakso Ikan (Rastrelliger Kanagurta) dengan subtitusi wortel (Daucus Carota) Universitas Semarang 1-7

Gultom OW, Lestari S, Nopianti R. 2015. Analisis proksimat, protein larut garam pada beberapa jenis ikan air tawar sumatera selatan. Jurnal Fishtech. 4(2):120-127

Hadinoto S. Kolanus J.P.M. 2017. Evaluasi Nilai Gizi dan Mutu Ikan Layang (Decapterus $s p$ ) presto dengan Penambahan Asap Cair dan Ragi. Majalah Biam 1-30

Insan I, Setijaningsih L, Suhendra N, Rusmaedi. 2004. Pengolohan Fitoplankton yang menimbulkan bau lumpur pada ikan gurami di kolam tadah hujan. Jurnal Penelitian Perikanan Indonesia. 10(5): 8191.

Irianto HE, Giyatmi S. 2009. Teknologi Pengolahan Hasil Perikanan. Penerbit Universitas Terbuka. Jakarta

Junianto. 2003. Teknik Penanganan Ikan. Penebar Swadaya. Penerbit: Jakarta.

Karim M, Aspari DNF. 2014. Pengaruh penambahan tepung karagenan terhadap mutu kekenyalan bakso ikan gabus. Jurnal Batik Diwa. 6(2):41-49

Kusumayanti H, W Astuti, Broto. 2011. Inovasi Pembuatan Abon Ikan sebagai Salah Satu Teknologi Pengawetan Ikan. Gema Teknologi. 16 (3):1.10.
Manuhara JG. Affandi RD, Aziza T. 2015. Bakso Ikan Tongkol (Euthynnus affinis) Dengan Filler Tepung Gembili Sebagai Fortifikasi Inulin. Jurnal Teknologi Hasil Pertanian. 8(2):77-83

Montolalu SN, Lontaan S, Sakul ADP, Mirah. 2013. Sifat fisika-kimia dan mutu organoleptik bakso broiler dengan menggunakan tepung ubi jalar (ipomoea batatas L). Jurnal Zootek. 32(5): 1-13.

Paliling IPH, Metusalach, Amir N. 2018. Kualitas Dan Kesukaan Bakso Ikan Nila (Oreochromis niloticus) Dengan Penambahan Ekstrak Karotenoid Dari Cangkang Udang Putih (Litopenaeus vannamei). Jurnal IPTEKS. 5(10): 132148.

Palupi TR, Setiawati M, Jusadi D, Fauzi FA, Wasjan. 2020. Evaluasi Periode Pemberian Pakan Mengandung Daun Kayu Manis Cinnamomum burmannii Terhadap Kualitas Daging Ikan Nila Oreochromis niloticus. Jurnal Pengolahan Hasil Perikanan Indonesia. 23(1): 178-185.

Purukan OPM. Mamuaja CF. Mandey LC. Mamahit LP. 2013. Pengaruh Penambahan Bubur Wortel (Daucus carrota) dan Tepung Tapioka terhadap sifat Fisiokimia dan sensoris Bakso Ikan Gabus (Ophiocephalus striatus) Universitas Sam Ratulangi. Manado. 1-11

Rozaliana, Siregar LAM, Bayu ES. 2013. Pengaruh a-Benzil Amino Purina dan a-Asam Ateta Naftalena terhadap pembentukan tunas tanaman nilam (Pogostemon cablin Benth) secara IN-Vitro. Jurnal Online Agroteknologi 1(3):626-637.

Setiawan A, Noor GE, Fadli M, Murdimanto A. 2016. Profil Kelautan Dan Perikanan Kabupaten Kepulauan Sangihe Dan Kabupaten Kepulauan Talaud, Propinsi Sulawesi Utara. Penerbit: Puslitbang Sumberdaya Laut Dan Pesisir Badan Litbang Kelautan dan Perikanan Kementerian Kelautan dan Perikanan

[SNI] Standar Nasional Indonesia. 2014. Syarat Mutu dan Keamanan Bakso ikan (SNI7266:2014). Badan Standarisasi Nasional.

Subagio A, Windrati WS, Fauzi M, Witono Y. 2003. Karakterisasi protein miofibril dari ikan kuniran (upeneus moluccencis) dan ikan mata besar (Selar crumrnophthalmus). Jurnal Teknol dan Industri Pangan. 15(1). 
Tondais J, Sombo DE, Lalenoh BA, Mappiratu M, Adrian A, Cahyono E. 2020. Ekstraksi Flavour dari Tepung Ikan Layang (Decapterus sp.) Menggunakan Enzim Protease Biduri (Calotropis gigantea). Jurnal FishtecH. 9(1):6-12

Winarno F G. 2004. Kimia Pangan dan Gizi. Penerbit: Gramedia Pustaka Utama. Jakarta.
Wodi SIM, Cahyono E, Kota N. 2019. Analisis Mutu Bakso Ikan Home I ndustri dan komersil di Babakan raya Bogor. Jurnal FischtecH. 8(1): 7-11

Zamili S, Hulu M, Irmawati, Sihombing SF. 2020. Pembuatan Bakso Dari Daging Ikan Tongkol (Euthynnus affinis). Journal of Chemistry, Education, and Science. 4(1):14-18 